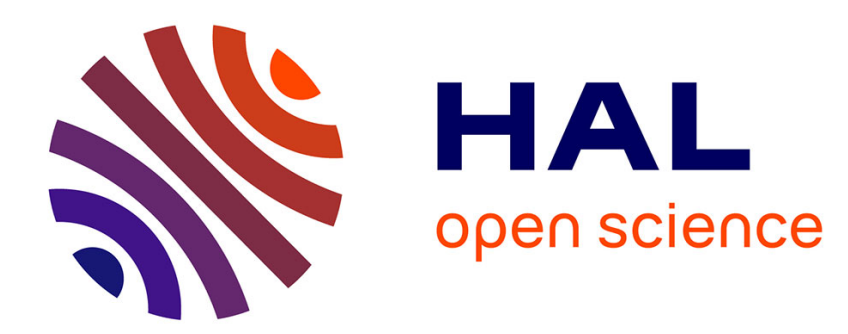

\title{
HIGH-STRAIN-RATE BEHAVIOUR OF CP-271 ALUMINIUM-LITHIUM
}

\author{
C. Chiem, Xin Zhou, W. Lee
}

\section{To cite this version:}

C. Chiem, Xin Zhou, W. Lee. HIGH-STRAIN-RATE BEHAVIOUR OF CP-271

ALUMINIUM-LITHIUM. Journal de Physique Colloques, 1987, 48 (C3), pp.C3-577-C3-586. 10.1051/jphyscol:1987367 . jpa-00226598

\section{HAL Id: jpa-00226598 https://hal.science/jpa-00226598}

Submitted on 1 Jan 1987

HAL is a multi-disciplinary open access archive for the deposit and dissemination of scientific research documents, whether they are published or not. The documents may come from teaching and research institutions in France or abroad, or from public or private research centers.
L'archive ouverte pluridisciplinaire HAL, est destinée au dépôt et à la diffusion de documents scientifiques de niveau recherche, publiés ou non, émanant des établissements d'enseignement et de recherche français ou étrangers, des laboratoires publics ou privés. 


\title{
HIGH-STRAIN-RATE BEHAVIOUR OF CP-271 AIUMINIUM-IITHIUM
}

\author{
C.Y. CHIEM, X.W. ZHOU and W.S. LEE \\ Ecole Nationale Supérieure de Mécanique, Laboratoire des \\ Sciences des Matériaux de la Mécanique "ENSM-IMPACT", 1, Rue de \\ Ia Noë, F-44072 Nantes Cedex, France
}

\section{EXTENDED ABSTRACTS}

Among advanced materials for transport, the low density aluminium-1ithium alloy look particularly attractive for the aeronautic and aerospace industries.

The main topic of this study is aimed to focus the correlation of the fundamental mechanisms with respect to the high strain-rate behaviour of the cP-271 aluminiumlithium alloy.

Specimens have been deformed in compression and torsion at strain-rate range from $10^{-3} \mathrm{~s}^{-1}$ to $10^{4} \mathrm{~s}^{-1}$; the dynamic testing is done by the split-Hopkinson bars method.

Comparison of the results between quasi-static and dynamic behaviour is done. CP-271 aluminum lithium alloy is quite sensitive to strain-rate. The testing results and the microscopic observation prove that the heat-treatment conditions have a great influence on the dynamic rupture property of the aluminium-1ithium alloys.

These basic mechanical properties and microstructure relationships will help to a better comprehension of the behaviour of these Al-Li alloys. In addition, it helps to set up a guideline for the selection of a more promising microstructure for a better impact strength of the material.

\section{INTRODLCTION}

Recently, adding lithium to high strength aluminium alloy has been widely know as one of the main materials for aircraft part-members due to its attractive combination of low density, high specific elastic modulus and high specific strength. So far, a number of research works on the mechanical behaviour and physical characteristics of Al-Li alloys under quasi-static testing conditions have been carried out (1), however, the high strain rate behaviours, such as mechanical properties, microstructure characteristics, dislocation and deformation mechanisms, are still considered as important works to be performed urgently.

Lany authors have made experiments to explain some F.C.C. metals behaviour at high strain rates. The split Hopkinson bar technique has been applied to investigate the dynamic behaviour in compression (2) or tension (3) of various materials and has shown great strain rates and strain-history effects on the behaviour of these metals. Under these circumstances, there are athermal, thermally activated, diffusioncontrolled and dislocation-drag controlled mechanisms (4) which control the deformation rate of metals. Furthermore, when the strain rate is lower than $10^{3} \mathrm{~s}^{-1}$, the dominant rate controlling mechanism for dislocation motion shows the above mentioned mechanisms except drag. While the strain rate is higher. than about $10^{3} \mathrm{~s}^{1}$, the strain. rate sensitivity of the flow stress increases rapidly. 
During dynamic loading, the change of microstructure occurs and the result of this change reflects upon different stress states, strain or strain rate path. At high velocity deformation, the deformation mechanism changes from slip to twinning in accordance with stress. Some of the researchers have explained the microstructure change by dislocation theory (5) and described the dislocation dynamics at high strain rate. Actually, the dislocation distribution characteristics for shocked aluminium have been reported (6), and cell structure of dislocations was found in dynamic deformation (7). For example, for copper (8), dislocation cell structures are formed at about $1 \times 10^{2} \mathrm{~s}^{-1}$; for aluminium single crystal (9), the cell size will reduce if the flow stress and the strain rate sensitivity are increased. The objective of this investigation is to describe the experimental results which are obtained by torsion tests in the strain rate range of $10^{-3} \sim 10^{4} \mathrm{~s}^{-\frac{1}{1}}$ and compression tests within $10^{2} \sim 10^{4} \mathrm{~s}^{-1}$. Several observations of microstructure change at different strain rates are presented.

\section{EXPERIMENTAL PROCEDURES}

\subsection{Preparation of specimens}

The material used is provided by the Centre de Recherche de Voreppe, CEGEDUR PECHINEY. Its composition and heat treatment conditions are listed in table I. Static mechanical properties are detailed in references (10), (11).

\begin{tabular}{|c|c|c|c|c|c|c|c|c|c|}
\hline \multicolumn{10}{|c|}{$8090-\infty 271$} \\
\hline ar & II & gy & re & si & $\alpha$ & m & $8 \mathrm{n}$ & Ti & $\mathbf{2 r}$ \\
\hline $7.0-1.6$ & $2.2-2.7$ & $0.6-1.3$ & $<0.30$ & $<0.20$ & $<0.10$ & $<0.10$ & $<0.25$ & $<0.10$ & $0.04-0.16$ \\
\hline \multicolumn{5}{|c|}{$1416 \mathrm{M}$ (texpered $12 \mathrm{~h}-190^{\circ} \mathrm{C}$ ) } & \multicolumn{5}{|c|}{$1416 \mathrm{~T}\left(\right.$ tempered $\left.2 \mathrm{~h} 3 \mathrm{~h}-160^{\circ} \mathrm{C}\right)$} \\
\hline
\end{tabular}

Table I. Alloy composition (in weight percent) and heat treatment conditions.

The shape of the specimens tested for the torsional experiment is shown in $\mathrm{Fig}$. 1 ; the specimens are machined in a thin-walled tube with flanged ends which are cemented to the Hopkinson bar using an epoxy adhesive.

The specimens for the compressive tests are cylindrical ; they are classified into two groups, one is parallel to the rolling direction and the other perpendicular to the rolling direction. After deformation, the specimens were sliced and polished in order to get thin foils for transmission electron microscope (TEM) observations.

\subsection{Mechanical testing by torsion and compression Hopkinson bars}

The specimens have been deformed in compression and torsion at strain-rate ranging from $10^{2} \mathrm{~s}^{-1}$ to $10^{4} \mathrm{~s}^{-1}$ and $10^{-3} \mathrm{~s}^{-1}$ to $10^{4} \mathrm{~s}^{-1}$ respectively. The split-Hopkinson bars are used for the tests.

Fig. 1 and Fig. 2 show respectively the general arrangement of the torsional and compression test assemblies with Lagrangian wave propagation diagram on the torsional testing device.

The testing systems are composed of three parts : pulse generation system, pulse detecting and recording system: and data processing system. Since the description of the apparatus and experimental procedure have been detailed in ref. (12) (13) and (14). Only a brief account of them is given here.

Both torsional and compressive tests are based on the theory of the propagation of one-dimensional elastic-plastic stress wave in bars (Fig. 1). This latter has been discribed clearly by $H$. Kolsky (15). The only difference between them is the method of the pulse generation. The torsional pulse is stimulated by a sudden release of a torque stored in the incident bar between the rotating head and the clamp (Fig. 1), and the compressive pulse is generated by an impact between the projectile and the imput bar (Fig. 2). Then, the pulse propagates down the incident bar toward the specimen. At the incident bar/specimen and specimen/transmission bar interfaces, reflected and transmitted waves occur. The incident, reflected and transmitted pulses are detected in a conventional manner using electric-resistance strain gages and are recorded using a digital oscilloscope. The average stress and strain in the specimen can be calculated from the reflected and transmitted waves. In the torsional test (16) 


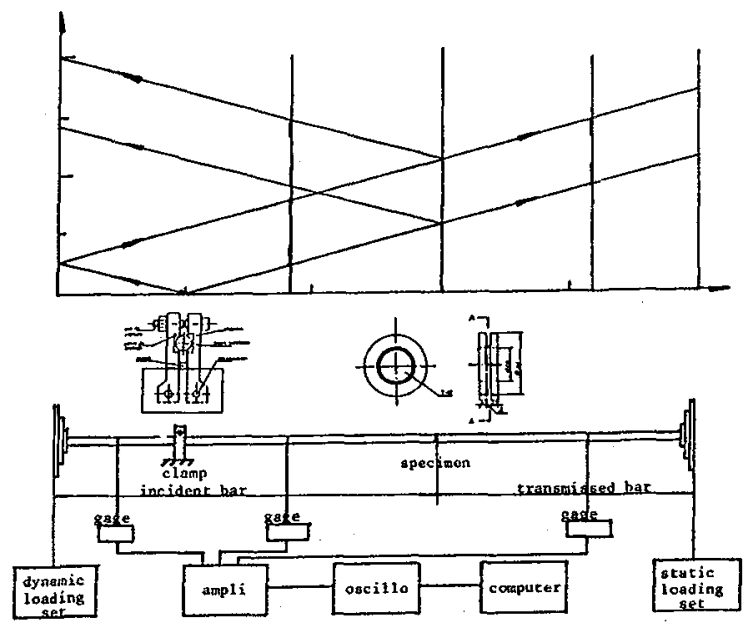

Fig. 1. Hop̆kinson bars in torsion and Lagrangian diagram

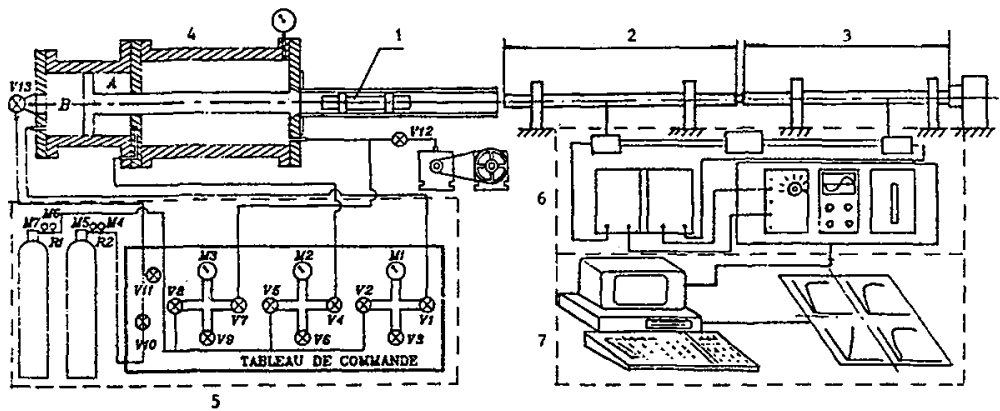

A: projectile 2:incident bax 3:transmission bar 4: launching system 5: pressure comand panel 6:apparatus signal recording systen 7: data processing.

Fig. 2. Compression test set

$$
\begin{aligned}
& \tau=\frac{G}{2} \frac{r_{e}^{3}}{e r_{m}^{2}} \gamma_{T}(t) \\
& \gamma=-2 \frac{C_{T} r_{m}}{L r_{e}} \int_{0}^{t} \gamma_{R}(t) d t
\end{aligned}
$$

where $\mathrm{G}$ is the shear modulus, $\mathrm{r}_{\mathrm{e}}$, the radius of the bars, $\mathrm{e}, \mathrm{r}_{\mathrm{m}}$ and $\mathrm{L}$ being the wall thickness, the mean radius and the gauge length of the specimen respectively. $C_{T}$ is the velocity of the transverse wave in the bar, $\gamma_{T}$ and $\gamma_{R}$ being the transmitted and reflected waves recorded by oscilloscope.

In the compressive experiments (17)

$$
\begin{aligned}
& \sigma=E\left(\frac{A}{A_{0}}\right) \varepsilon_{T} \\
& \varepsilon=\frac{2 C_{0}}{L_{0}} \int_{0}^{t} \varepsilon_{R} d t
\end{aligned}
$$


where $\mathrm{E}$ is the Young's modulus, A, the cross-sectional area of the bars, $\mathrm{L}$ and $\mathrm{A}$, the initial length and cross-sectional area of the specimen. $\varepsilon_{T}$ and $\varepsilon_{R}$ represent the instantaneous amplitudes of the reflected and transmitted pulses respectively.

The quasi-static test in torsion is performed at the same apparatus as that used in dynamic torsional test. The displacement is detected by a DCDT (Direct Current displacement transducer) (Fig. 3). The torque is measured by the electrical-resistance strain gage, the stress and strain can be obtained according the following formular :

$$
\begin{aligned}
& \tau=\frac{\mathrm{G} \mathrm{r}_{\mathrm{e}}^{3}}{2 \mathrm{r}_{\mathrm{m}}^{2}} \gamma_{\mathrm{T}} \\
& \gamma=\frac{\mathrm{r}_{\mathrm{m}}}{\mathrm{r}_{\mathrm{e}}} \frac{1}{\mathrm{~L}} \frac{\mathrm{U}}{\mathrm{S}} \bar{U}_{\mathrm{o}}
\end{aligned}
$$

where, $S$ is the sensitivity of the transducer, $U$ being the voltage of the power supply. $U$ is the instantaneous amplititudes of the displacement signal.

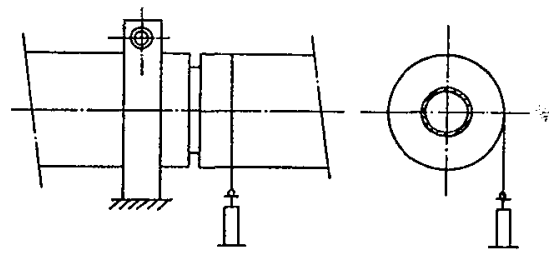

Fig. 3. Displacement transducer

\subsection{Microstructure observation}

The microstructure of the alloys is characterized by using scanning and transmission electron microscope. Thin foils for T.E.M. are prepared by electropolishing $3 \mathrm{~mm}$ diameter by $0.3 \mathrm{~mm}$ thickness discs which were cut from compression specimens parallel and perpendicular to the rolling direction. The discs are electropolished in a double jet polishing apparatus operated at $25 \mathrm{~V}$ and room temperature with a circulating electrolyte which consists of $78 \mathrm{ml}$ perchloric acid, $700 \mathrm{ml}$ ethanol, $100 \mathrm{ml}$ butyl cellosolve and $120 \mathrm{ml}$ distilled water. Then they are observed in a JEOL $120 \mathrm{cx}$ Temscan, operating at $100 \mathrm{kV}$. The fractographic analysis of the torsion specimens are examined in a JEOL JSM-35C scanning electron microscope (S.F.M.) operated at $15 \mathrm{kV}$.

\section{RESULTS AND DISCUSSIONS}

\subsection{Shear stress-strain curves}

Experimental results in torsional tests are presented in Fig. 4 and Table 2.

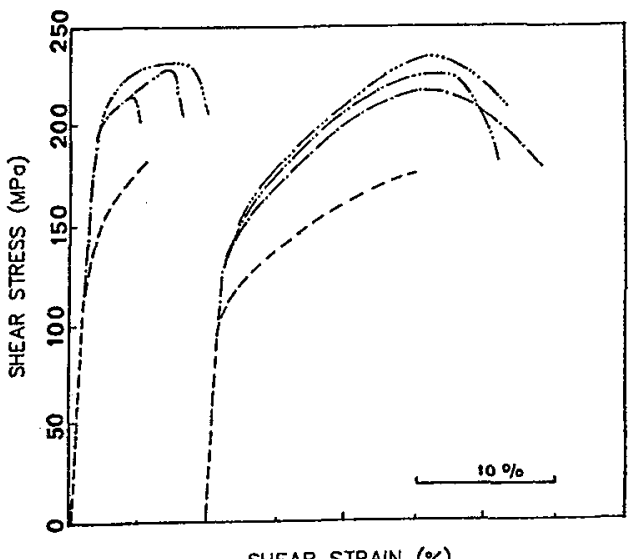

\begin{tabular}{|c|c|c|c|c|c|c|c|}
\hline \multicolumn{3}{|c|}{ CP271-12H-190 } & \multicolumn{3}{c|}{ CP271-2H30-160 } \\
\hline$\dot{\gamma}$ & $\tau_{y}$ & $\tau_{\text {max }}$ & Symbo & $\dot{\gamma}$ & $\tau_{y}$ & $\tau_{\text {max }}$ & Smbo \\
\hline 2745 & 207 & 227 & $-\cdots$ & 3662 & 166 & 233.6 & $\cdots-\cdots-$ \\
\hline 1041 & 197 & 224.2 & $-\cdots-$ & 2071 & 159 & 224.7 & $\cdots-$ \\
\hline 405 & 187 & 213 & $-\cdots$ & 1087 & 145 & 218.2 & $-\cdots-$ \\
\hline $6.12 \times 10$ & 118.6 & 179.1 & $\cdots--$ & $3 \times 10^{3}$ & 106.8 & 180.7 & $-\cdots$ \\
\hline
\end{tabular}

Table 2. Values taken from Fig. 4

Fig. 4. Shear stress-strain curves 
From Fig. 4, we can see that $1416-\mathrm{M}\left(12 \mathrm{~h}\right.$ at $190^{\circ} \mathrm{C}$ ) and $1416-\mathrm{T}$ (2h30 at $\left.160^{\circ} \mathrm{C}\right)$ have different behaviours. At the same strain-rate, the maximum stress of $1416-\mathrm{M}$ is greater than that of $1416-T$, and, 1416-M shows a more brittle behaviour. If, in the tests of 1416-M, we use the same specimen dimensions as in 1416-T tests, we can never reach the same maximum strain-rate, even if we change the dimensions of specimens, we could not reach a strain-rate as high as that in $1416-\mathrm{T}$ tests. This is due to the very small amount of plastic strain in 1416-M.

We can also notice that for both $1416-\mathrm{M}$ and $1416-\mathrm{T}$, the dynamic curves lie above the static ones, and maximum strain in static tests is less than that in the dynamic experiments. Among the dynamic stress-strain curves, the plastic stress inhigher strain rate is a little more greater than that in lower strain-rate in the case of the same strain. For 1416-M, the maximum plastic strain in higher strain-rate is greater than that in lower strain-rate (from 2\%-8\%), but for 1416-T, the maximum plastic strain is almost the same in each test ( $\sim 12 \%)$.

\subsection{Strain-rate effect}

The variation of shear strength and yield stress with strain rate from $10^{-3} \mathrm{~s}^{-1}$ to $10^{4} \mathrm{~s}^{-1}$ are presented in Fig. 5 .

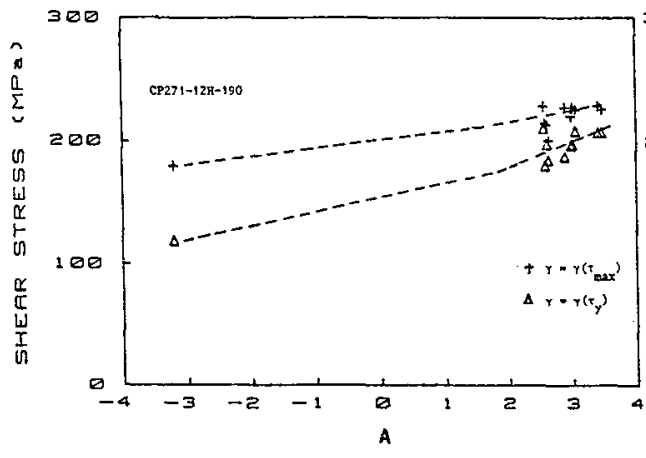

LOG (STRAIN-RATE $(s-12)$

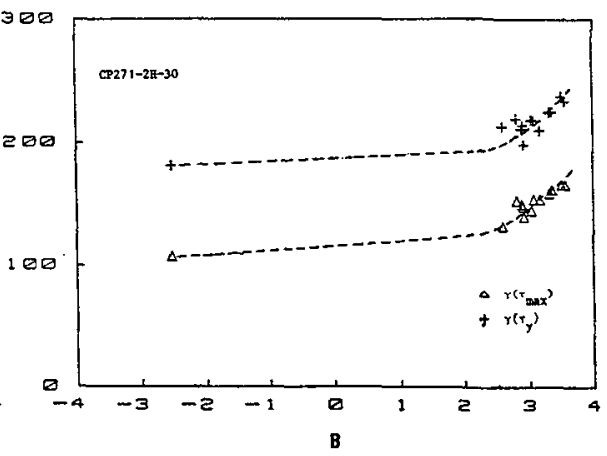

LOG (STRAIN-RATE $(s-1)$,

Fig. 5. Strain-rate dependence of shear strength and yield stresses, $A=1416-M, B=1416 \mathrm{~T}$

For the 1416-T, we can see that the curves are obviously divided into two parts, as most of the F.C.C. metals, the shear strength and yield stress increase rapidly with increasing strain-rate from $10^{2} \mathrm{~s}^{-1}$ to $10^{4} \mathrm{~s}^{-1}$. However, for $1416-\mathrm{M}$, at the whole range of strain-rate from $10^{-3} \mathrm{~s}^{-1}$ to $10^{4} \mathrm{~s}^{-1}$ the stress has almost a linear dependence to the strain-rate.

Fig. 6 show the relationship between shear stress and strain-rate (from $10^{2} \mathrm{~s}^{-1}$ to $10^{4} \mathrm{~s}^{-1}$ ) at various plastic shear strain.
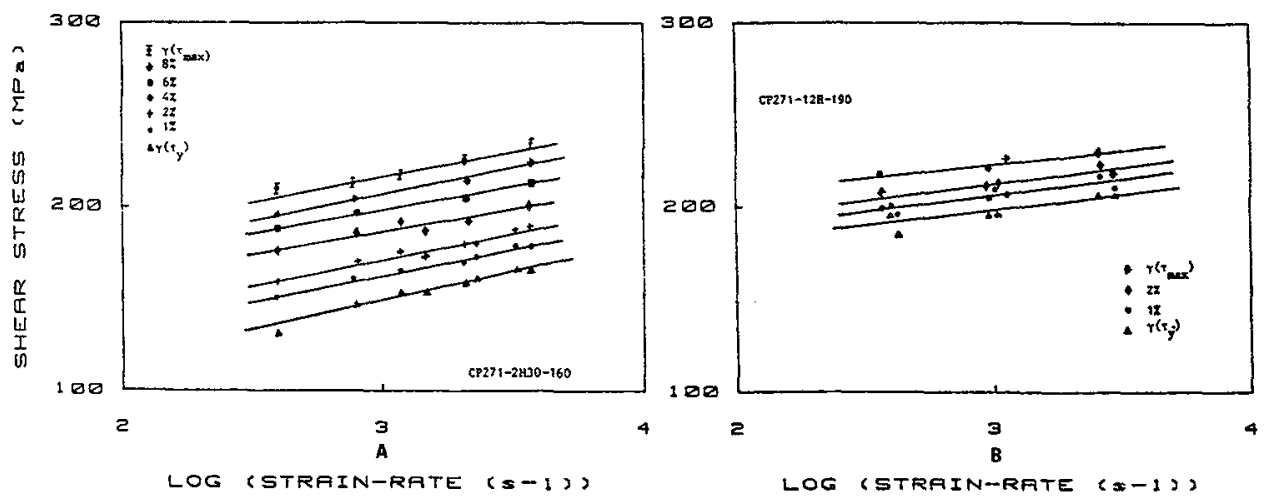

Fig. 6. Shear stress as a function of strain-rate, A : 1416-T, B : 1416-M 
From the figures, we could notice that a linear relationship exists. It $f i t s$ an empirical formula $\tau=A+B \log \gamma$ where $A$ and $B$ are correlation coefficients, which were calculated with the least square method. Table 3 gives the values of $A$ and $B$.

Table 3

\begin{tabular}{|c|c|c|c|c|}
\hline & \multicolumn{2}{|c|}{$\mathrm{CP} 271-12 \mathrm{H}-160$} & \multicolumn{2}{c|}{$\mathrm{CP} 271-12 \mathrm{H}-190$} \\
\hline & $\mathrm{A}$ & $\mathrm{B}$ & $\mathrm{A}$ & $\mathrm{B}$ \\
\hline$\gamma_{\mathrm{r}}$ & 135 & 27 & 176 & 15 \\
\hline 8 & 121 & 29 & & \\
\hline 4 & 111 & 25 & & \\
\hline 2 & 87 & 28 & 189 & 18 \\
\hline 1 & 76 & 29 & 180 & 18 \\
\hline$\gamma_{\mathrm{r}, \mathrm{y}}$ & 55 & 31 & 148 & 17 \\
\hline
\end{tabular}

The strain-rate sensitivity is known as $\frac{\partial \tau}{\partial \log \dot{\gamma}}$. We can note that the coefficient $B$ represents the strain-rate sensitivity. In the strain-rate range from $10^{2} \mathrm{~s}^{-1}$ to $10^{4} \mathrm{~s}^{-1}$, the values of $B$ are almost independent of the shear strain; for 1416-M, $B$ changes between 15 and $18 \mathrm{MPa}$. For $1416-\mathrm{T}$, from 25 to $31 \mathrm{MPa}$, B can be regarded as a constant. If we consider the strain-rate range from quasi-static to dynamic values (i.e., $10^{-3}$ to $10^{4} \mathrm{~s}^{\mathrm{l}}$ ), CP271 $(1416-\mathrm{M})$ and CP271 (1416-T) are both strain-rate sensitive; however the second is much more sensitive than the first case.

Lindholm has defined the strain-rate sensitivity in the range of the thermally activated mechanisms (18) under the following form :

$$
\lambda=\frac{1}{\sigma_{0}} \frac{\mathrm{d} \sigma}{\mathrm{d} \log \dot{\varepsilon}}
$$

where $\sigma_{0}$ is the flow stress for a known strain-rate. Using this definition, Fig. 7 shows the comparison of strain-rate sensitivity of CP271 and that of other a11oys(19).

This allows to distinguish the alloying effect of the lithium on the aluminium matrix and also the heat-treatment effect. We can notice that 1 ithium shows a medium alloying effect in CP271. Concerning the heat treatment conditions, the 1416-T yields a more important strain-rate sensitivity than the $1416-\mathrm{M}$ condition.

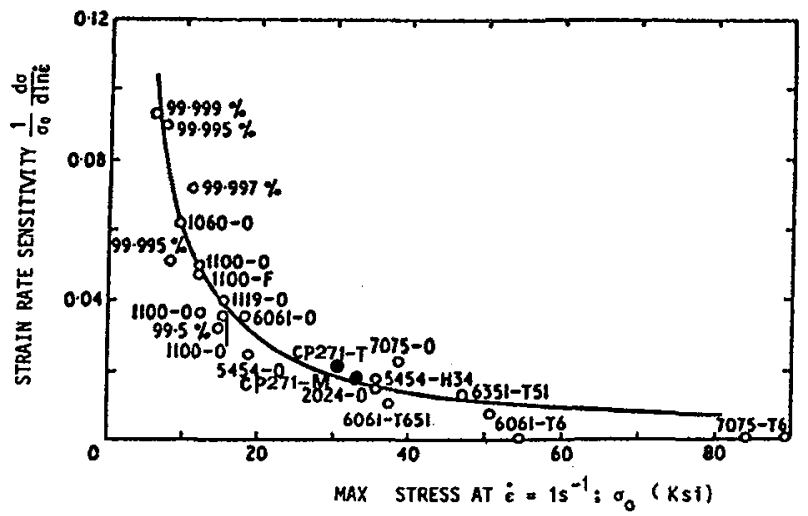

Fig. 7. Values of strain-rate sensitivity as a function of the maximum stress in various aluminium alloys 


\subsection{Fracture appearance of the specimens}

Scanning electron micrographs of the surface of the torsion specimens are shown in Fig. 8 and Fig. 9 which show that the fracture surfaces in all the test conditions are brittle and that various cleavage structures exist on the fracture surface, corresponding to a brittle fracture mode. For $1416-\mathrm{T}$ conditions $\left(2 \mathrm{~h} 30\right.$ at $160^{\circ} \mathrm{C}$ ), when the strain rate is low $\left(\varepsilon=550 \mathrm{~s}^{-1}\right.$, Fig. 8a), numerous small cleavages are seen so evidently on the fracture surface that they are enough to prove a low ductility. If the strain rate is increased to $\dot{\varepsilon}=2000 \mathrm{~s}$ (Fig. 8b), the large cleavage facets are found. This result makes a counter reaction to ductility. In other words, the ductility will decrease when strain rate is increased. For $1416-\mathrm{M}$ condition ( $12 \mathrm{~h}$ at $190^{\circ} \mathrm{C}$ ), at small strain rate $\left(\dot{\varepsilon}=350 \mathrm{~s}^{-1}\right.$, Fig. 9a), a lower strength and a poor ductility appear. But at large strain rate $\left(\dot{\varepsilon}=1000 \mathrm{~s}^{-1}\right.$, Fig. 9b), we got reverse correlation between strength and ductility. Anyway, their fracture surfaces are still brittle fractures. On the other hand, at $\dot{\varepsilon}=1000 \mathrm{~s}$ the fracture surface shows an intersubgranular fracture, comparing this with that of $\mathrm{Fig} .8 \mathrm{~b}$, the fracture process a1ters from transgranular to intersubgranular and the ductility drops accordingly. In short, the fracture surface varies with strain rate and heat treatment condition, and the fracture modes are related to these two parameters. Although the ductility variation with strain rate is an apparent tendency, the effect of heat treatment condition should be larger than that of strain rate, because, generally, the higher heat treatment temperature and the longer holding time enhance a faster decrease of the ductility.

\subsection{Microstructures}

The microstructure of compression specimens deformed at room temperature under different strain levels are shown in Fig. 10 for the $1416-\mathrm{T}\left(2 \mathrm{~h} 30\right.$ at $\left.160^{\circ} \mathrm{C}\right)$ and in Fig. 11 for the $1416-\mathrm{M}\left(12 \mathrm{~h}\right.$ at $\left.190^{\circ} \mathrm{C}\right)$ and their different characteristics have been evidenced by dislocation aspects. Also, all the below mentioned samples are taken perpendicular1y to the rolling direction.

The undeformed specimens of the $1416-\mathrm{T}$ ( $2 \mathrm{~h} 30$ at $\left.160^{\circ} \mathrm{C}\right)$ show dislocations distributed evenly in the matrix as in Fig. 10a; the microstructure consists of dipole trails and pinch off dipoles. For those specimens tested at $3.8 \%$ strain, there are dislocation pile ups with some arrangements which tend to produce dislocation cells (Fig. 10b). If we increase the strain to $9.3 \%$, a dislocation cell structure is produced and a larger cell size can be seen (Fig. 10c). When test is run to large strain value as $15.5 \%$ (Fig. 10d), the increase of dislocation density and plastic strain result in a decrease of the mean dislocation cell size, therefore, a larger stress is needed for further deformation.
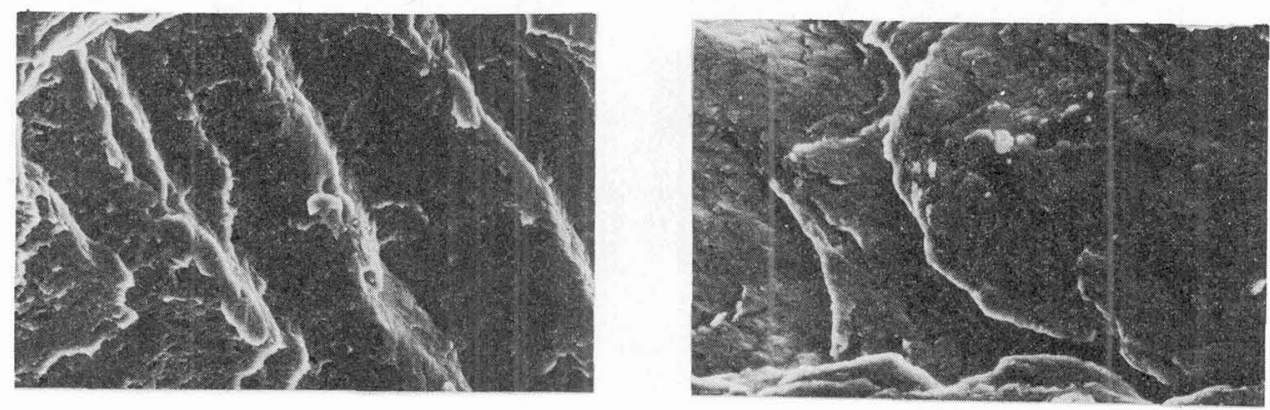

(a) Fig. 8. Scanning electron miçrographs of torsion specimens of CP271 tempered for
$2 \mathrm{~h} 30$ at $160^{\circ} \mathrm{C}$, (a) $\dot{\varepsilon}=550 \mathrm{~s}$, (b) $\dot{\varepsilon}=2000 \mathrm{~s}^{-1} \times 1000$ 


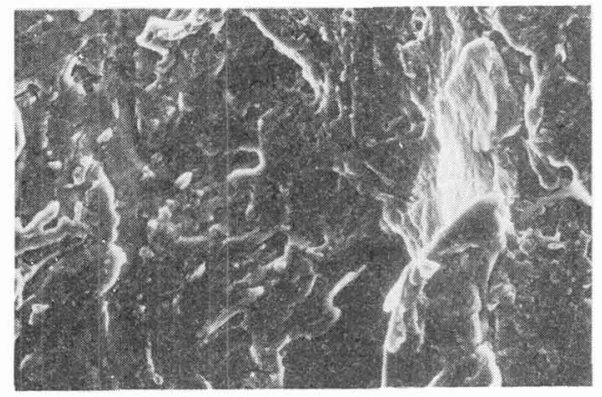

(a)

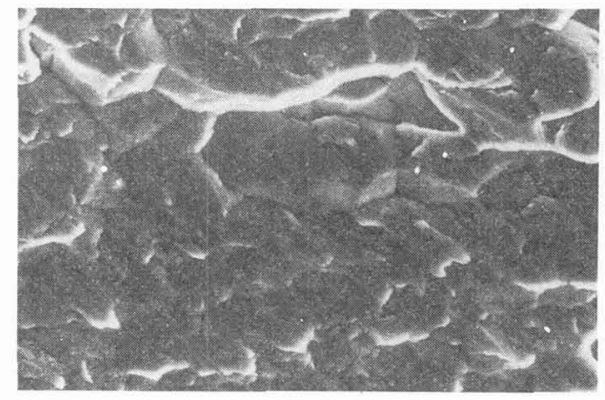

(b)

Fig. 9. Scanning electron micrographs of torșion specimens of CP271 tempered for $12 \mathrm{~h}$ at $190^{\circ} \mathrm{C}$, (a) $\dot{\varepsilon}=350 \mathrm{~s}^{-1}$, (b) $\dot{\varepsilon}=1000 \mathrm{~s}^{-1} \cdot \times 1000$

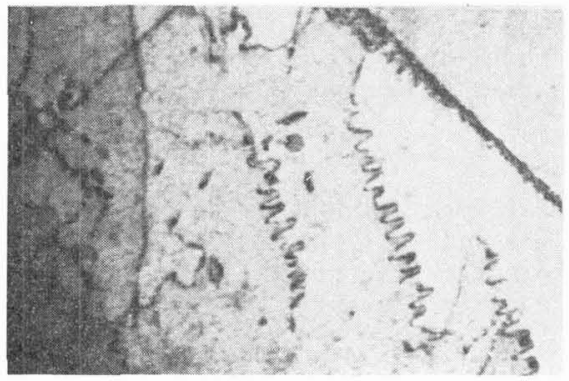

(a)

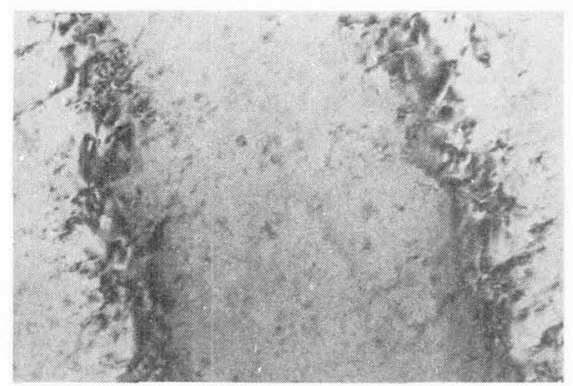

(c)

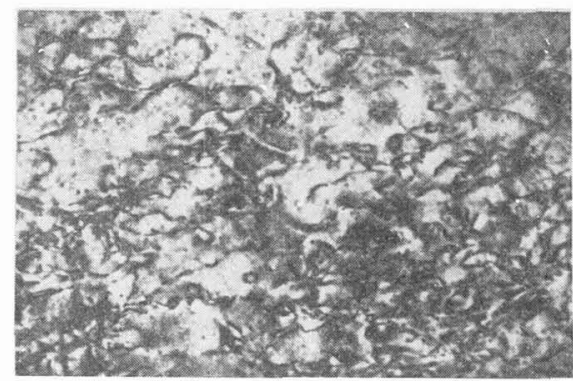

(b)

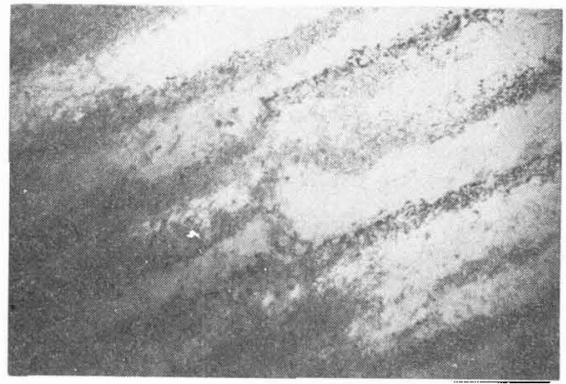

(d)

Fig. 10. Transmission electron micrographs of specimens for $2 \mathrm{~h} 30$ at $160^{\circ} \mathrm{C}$, deformed in room temperature to different strain levels. (a) undeformed, (b) $3.8 \%$, (c) $9.3 \%$, (d) $15.5 \% . \times 50000$

For specimens of undeformed $1416-\mathrm{M}\left(12 \mathrm{~h}\right.$ at $\left.190^{\circ} \mathrm{C}\right)$, there is a $S^{\prime}$ phase precipitation in the matrix. This phase produces:a stress field which creates a larger strength against dislocation motion, so that, the dislocations surronding with $s^{\prime}$ forms needle shape structure (Fig. 11a). If strain is continously increased, the dislocations gather again into a microstructure of forest dislocations with clustered defects (Fig. 11b, Fig. 11c), finally, dislocation cells are shaped at $15 \%$ strain. By comparing the strain value with Fig. 10 and Fig. 11 , dislocation cells of Fig. 11 are formed much later than that of Fig. 10. In case where samples are cut parallel to the roliing direction, the similar result can be obtained. This situation explains that microstructural changes versus strain values have no concern with rolling direction, they are much sensitive to heat treatment conditions. 


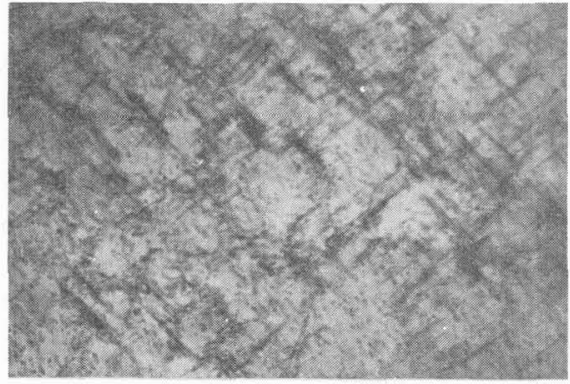

(a)

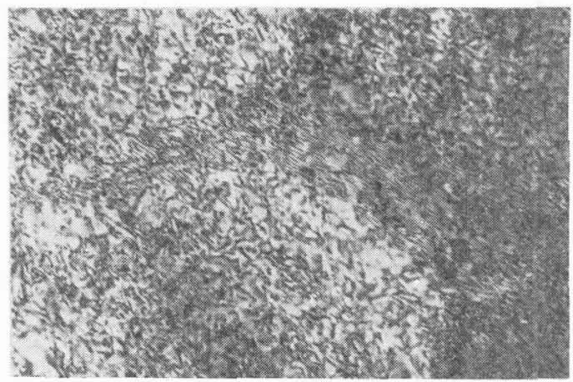

(c)

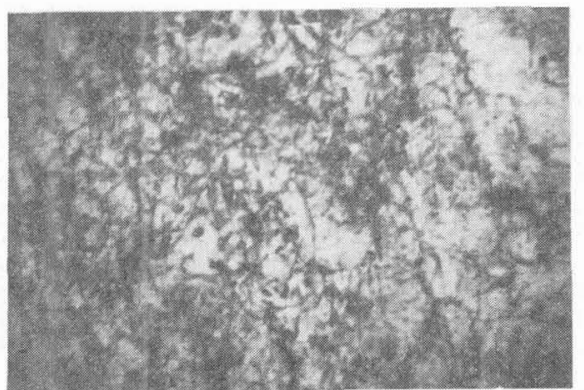

(b)

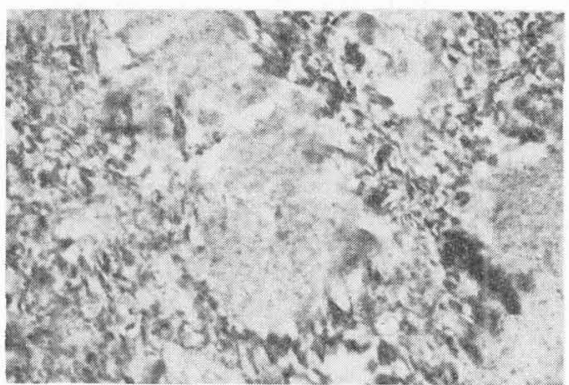

(d)

Fig. 11. Transmission electron micrographs of specimens for $12 \mathrm{~h}$ at $190^{\circ} \mathrm{C}$, deformed in room temperature to different strain levels.

(a) und eformed, (b) $4.4 \%$, (c) $2.4 \%$, (d) $15 \% . \times 50000$

\section{CONCLUSIONS}

Three major results are obtained fxom the mechanical behaviour studies : (1) Al- $\mathrm{Li}$ alloys of the CP271 type is strain-rate sensitive and also very sensitive to heat treatment conditions. (2) at two different heat treatment conditions, 1416-T yields a more important strain rate sensitivity than the 1416-M condition. (3) by comparing the strain rate sensitivity of CP271 Al-Li alloys to that of other light alloys and pure or commercial Al, it has shown that lithium's contribution to the strengthening of the aluminium base is medium.

Higher heat treatment temperature and longer holding times yield a poor ductility for this alloys. The various dislocation structures of undeformation samples are made by solubility products of lithium in aluminium as a function of temperature. The dislocation cells formed under each condition at different strain values, and the decrease of cell size is related to the increase of stress due to strain rate effect. Cleavage fracture surfaces of this alloys present low ductility characteristics and poor fracture toughness for strain-rate higher $10^{3} \mathrm{~s}^{-1}$, therefore, how to improve these two weak points to obtain better mechanical properties is still a work needed to be fulfilled further.

ACKNOWLEDGMENTS

The authors wish to thank Mr. Philippe MEYER for his help with the experimental works and to Miss Martine DAMAS for the typing of the manuscript:

\section{REFERENCES}

(1) W.R.D. Jones and P.P. Das, Journal of the Institute of Metals, vol. 88, 1959 1960 pp. 435-443.

(2) A. Kunar and R.G. Kumble, J. App1. Physies. 40-9 (1969), pp. 3475-3480.

(3) J.R. Klepaczko and J. Duffy, Institute of Physics Conf. Ser. $n^{\circ} 21$ (1974).

(4) H. Neuhäuser, ICSMA5, "Strength of metals and alloys", vol. 3, pp. 1531-1550.

(5) R.W. Hertzberg, "Deformation and fracture mechanics of engineering materials", 1976. 
(6) M.F. Rose and T.L. Berger, Phil. Mag. 17, 1121 (1968).

(7) J.W. Edington, Phi1. Mag. 19 (1969), 1189-1206.

(8) J. Shioiri, K. Satoh and K. Nishimura, IUTAM Symposium Tokyo/Japan, 1977, p.50-66.

(9) C.Y. Chiem and J. Duffy, Brown University Report NSF ENG 75-18532/9 (1979).

(10) P. Meyer and B. Dubost, "Production of Aluminium-lithium alloy with high specific properties", 3rd International Aluminium-Lithium Conference, 8 July 1985, Oxford.

(11) P. Sainfort, B. Dubost, P. Meyer, "Basic Hardening Mechanisms in AluminiumLi thium A1loys", European Materials Research Society Fa11 Meeting, 26-28 nov. 1985.

(12) C.Y. Chiem and Z.G. Liu, 1985b, Annales des Composites, comportement au choc des matériaux et des structures composites, Villeurbanne, 12 décembre 1985.

(13) C.Y. Chiem and Z.G. Liu, 1985a, Compte-rendu ENSM-GIS Composite, avri1 1985.

(14) R. Boutemeur, Thèse Docteur Ingénieur, Nantes, 1985.

(15) H. Kolsky, "Stress waves in solids",Dover, New-York, 1963

(16) C.Y. Chiem, Thèse Nocteur-ès-Sciences, Nantes, 1980.

(17) U.S. Lindholm.Teehniques of Metals Research VOL.V pp199-271 1968

(18) U.S. Lindholm, R.L. Bessoy and G.V. Smith, J. of Materials, 6 (1), 119-133 (1971).

(19) F.E. Hauser, J.A. Simmons and J.E. Dorn, Response of Metals to High Velocity. Deformation. Ed. P.G. Shewmon and V.F. Zackay, N.Y. Interscience (1961). 